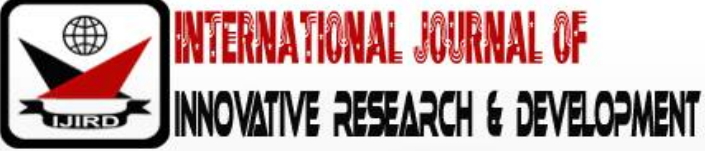

ISSN 2278 - 0211 (Online)

\section{Traditional Conflict Resolution Approaches in Annang Tribe of Akwa Ibom State, Nigeria}

\author{
Michael J. Denis \\ M.Sc. Student, Department of Peace and Conflict Studies, Center for Conflict and Gender Studies (CCGS), \\ University of Port Harcourt, Rivers State, Nigeria
}

\begin{abstract}
:
This study acknowledges that the Annang tribe had a long history of indigenous conflict resolution mechanisms and peace building processes aimed at sustainable reconciliation. In Annang, conflict resolution was done on the basis of institutional hierarchy and nature of conflict. This offers insight on how rigorous, community-based, victim-offender oriented and symbolic of culture and customs of the people the Annang conflict resolution mechanisms were. This paper used the historical approach in its findings which comprises the quantitative and qualitative methods of data analysis. It observes in its findings that while some of her customary conflict resolution methods may limp, the traditional institution remains invaluable for its core aim and preoccupation in every conflict resolution, which is the restoration of relationships. It summits that these Annang conflict resolution models, no doubt, will help in managing and resolving contemporary conflict issues especially where the western model seems inadequate and inaccessible.
\end{abstract}

Keywords: Annang, conflict, resolution, reconciliation, arbitration, peace

\section{Background of the Study}

Ancient Annang society was relatively peaceful. This does not negate the fact that there were issues of conflict. This social harmony owes much to the ways that conflictive issues were handled. Their models of conflict resolution were enshrined in the Annang traditional institution and judicial system. Because of its effective, it has served as a paradigm for conflict resolution through the ages, and so could not be easily eroded even after decades of colonization and modernization.

\subsection{Statement of Problem}

There is a seemingly intractable upsurge of conflicts in our society; the Annang nation is not impervious to this phenomenon. Remarkably, in the midst of this rising level of conflicts is the effort of formal legal system, state mercenary and regular courts to bring about peace. Evidences, however, show that these efforts are not yielding significant results as conflicts are prolonged, become impoverishing, breed animosity, and even exacerbated. These inadequacies call for a pertinent search for alternative mechanisms for managing conflicts. Consequently, it is our belief that the traditional conflict resolution mechanisms, especially the Annang models, will help mitigate this problem.

\section{Aims and Objectives of the Study}

The aim of this work is to revisit, reexamine and recommend certain values of conflict resolution in the Annangtribe of Akwa Ibom state, being part of the African traditional society. These values shall be carefully analyzed with due critical appraisal. Its preoccupation will reach a climax at recommending the use of Annang traditional conflict mechanism to compliment the western legal systemfor a better approach to conflict management.

\subsection{Introduction}

Afon inyene ntanga, ifono inana! (Literally, it means "It is better to have someone to quarrel with than to lack one"). This popular Annang proverb captures holistically the reality, inevitability and even the necessity of conflict in human relationship. With this Annang understanding of conflict, even though one is very troublesome within the family circle, his family members still value him and can never desert him in times of trouble and does everything to support such a person if eventually involved in dispute with an outsider.

Annang traditional institutions had a well-defined jurisprudence and legal system before the advent of colonialism. The laws which represented the customs and traditions of the people were the only veritable channels to peace and order in the society. Issues of conflict were therefore considered an infringement of the law and disrespect for customs and traditions. And this is why reintegration, reconciliation and relationship-building remain the hallmarks of traditional approaches to conflict in Annang tribe. 
We shall begin this discussion with an analysis of basic concepts, attempt an understanding of Annang judicial system and their quest for peaceful co-existence. We shall critically appraise the Annang institution and how they handle conflicts at their different tiers. Crucial to this, is how they applied, through rituals, different tools to arrive at reconciliation. The contemporary relevance of these mechanisms, their strengths and weaknesses shall also be of interest. These underpinning objectives will demonstrate at the surface how effective it will be for the traditional approaches not just to compliment the western models of conflict resolution, but to be given a pride of place especially for matters falling within the jurisdiction of customary authorities.

\subsection{Conceptual Analysis}

\subsubsection{Conflict}

Conflict is generally defined as goal incompatibility. Conflict exist when two or more groups struggle over values and claims to status, power and resources in which the opponents seek to neutralize, injure or eliminate the other party. (Jeong, 2000). It means an existing state of disagreement or hostility between two or more people (Nicholson, 1992). Conflict does not necessarily mean hostility or war. It may denote just 'a different perception' of something (Barash and Webel,2002). However, conflict often manifest in discord, struggle, contest, disharmony, feud, clash, contest, rivalry, fight, and the likes.

\subsubsection{Annang}

Annang is one of the three tribes in Akwa Ibom state, of which Ibibio and Oron are among. They are in the NorthWestern part of the state. Essien (2011) observes that the name "Annang" tends to have a cosmological origin from the name "Anaan", which means vastness. He further observes that this ignites in them a sense of struggle for survival often seen in their exhibition of courage, prowess, heroism and doggedness which affirms the proverb "agwo annang ade agwo uko." Hence, "Annang" seems to have affinity with inaanga (Hyper courageous person), nnanga (work), Unaang (fierce), ibannang (twosome heroes), enang (Cow), anaanga (tug of war) (Udondata and Ekandem, 2011 in Essien, 2011).

\section{Annang Judicial System}

The Annangs had their native laws. These laws did not only spell out duties and obligations, but also prohibitions and sanctions in cases of disobedience, conflict or violence. The Annang legal system and jurisprudence was categorizedinto customs (Eru-unam mkpo), laws (Mbed), duties and obligations (Utom), taboos (Ibed) and etiquette/ manner (Iro) (Ephraim, 2011). These ingredients provided the legal system the yardstickfor testing behaviour and judging issues of conflict.

The Primitive Annangs were not ignorant of their rights as human beings. This was evident by the rate at which people sought for redress and justice whenever they felt their rights have been violated.

\subsection{Motif of Peaceful Co-Existence in Annangland}

The quest for peaceful resolution of conflicts in Annangland signals one of her values, which is peaceful coexistence. The Annang concept of peace is not about settling disputes but the maintenance of relationships, it is reconciliation not justice. This relationship-oriented model of reconciliation finds its basis inthe Annang cosmology. There is a firm belief that there are two worlds; the physical and the spiritual, both integrative and complimentary' (Etim, 2005). Since the Annang metaphysical reality is holistic, cyclical, interrelated and harmonious (Maduka 2009), the maintenance of order and harmony in the universe therefore requires the maintenance of corresponding conditions within the various kinship groups in the society as well (Ayittey, 1991).

Hence, in Annang understanding conflict was not only seen from the point of view of incompatibility of goals between two or more parties. Certain wrong doings were considered to be to topple the 'harmonious monism' severing the relationship between the physical and the spiritual. In this way the person offends the gods (adue ikpaisong). Whenever this cycle of relationship is severed, the peopleexpected a rejoining of the cycle (Njoiyo mbono), which is literally reconciliation.

\section{Annang Traditional Institution and Conflict Resolution}

Conflict resolution in Annang was not haphazard. It followed the ascending hierarchical structure of the Annang traditional institution. Traditional institution refers to the native rules and authorities that are used for dispute settlement (Gbenemene, 2018). In Annang, the traditional institutions rose from the lowest to the highest starting from the nuclear family (Ufok), extended relatives (Epuk), Village (awio/ isong) to Clan (Iman) with the clan head, called akuku ikpaisong. However, though family disputes were in many cases settled by the Ufok Head, the Ekpuk Council was the lowest judicial authority under the ancient judicial system. It should also be noted that the village council wasthe highest executive authority and that there is no evidence of the existence of an institutionalized clan authority for judging of cases(Essien, 2011) except for inter village matters.

The nature of a conflict determines the level of hierarchy where it can be addressed. There were conflicts at the inter-personal level, extended family, the village and the clan or town level. The political unit which the litigants came from was also of great importance and a determinant of the institution to address it. Cases involving husbands and wives, cowives, brothers and sisters, et cetera, were settled either in the nuclear family or extended family. Cases of misunderstanding between siblings were settled by the parents who ensured harmony was restored. In the absence or 
death of parents, the Amnangs look up to the elderly sibling as one who plays the role of the parents. Consequently, in events of conflict, the intervention of the eldest child is valid.

A wife had no right to report an ill-treatment by the husband to her parents, when she has not first reported it to her father-in-law, and a hearing given in her husband's family which often brings together the extended family members (Ekpuk). These include all those who have blood ties, headed by the Obong Ekpuk (Family Head). Any case that could not be settled by Ekpuk was referred to awio (Village) headed by the Obong awio (Village Head). The village council usually met at the village hall (afe isong), village square (anwa isong) or at the palace of the village head.

In an interview with John Bosco Ekanem at Abak, (2019), at the level of the village, conflict resolution takes a different dimension. Here the act of summoning a rival to the village council is technically referred to as Ukot Ikpe. The litigant must pay a certain amount of money which is the litigation fee (Akuk Ukot Ikpe), customarily referred to as anim atang. When the rival party is summoned, he is asked to pay an equivalent amount before he is allowed to say something. This ritual has made many to stay out of trouble on the pretext that they are not rich enough to afford anima tang, especially if trouble erupts with someone who may bring a huge sum for anima tang.

The case proceeds with the parties making their statements. Anyone who knew anything about the case or is interested in it might give evidence (Essien, 2011, 241) At this juncture, there is room for aboro nno.Aboro nno is anybody who maybe willing to speak in favour of or defend any of the parties. A popular saying nyeneke aboro nno(I don't have an advocate) corroborates this fact. The judicial authority after the hearing consults among themselves (aru) and announces their decision through an appointed speaker.

Whoever is found to be guilty is asked to pay and a sort of compensation (mkpe Utip) to the other party. This is in line with her principle of fairness and the restitutive character of Annang traditional institution. However, mkpe utip also signals a retributive bent in her justice administration especially in cases like theft and adultery. In serious cases like murder, capital punishment was often applied. Those who swore to the oath in guilt were often identified by their swollen bodies (Njiook). This also affected those who violated the ibed (taboos). Anyonewho went against the taboos was said to have "eaten the gods" (adia awasi) or "eaten the taboos" (adia ibed) (Essien, 2011).

Annang conflict resolution is total as well as dynamic. Those reconciled are supposed to express deep and overt signs of forgiveness and reconciliation. If any of these parties fail, the other has the right to raise alarm and the council gathers again until they are sure that both have accepted the outcome. However, reconciliation in Annang does not mean that people will not quarrel again, there is a constant recycling of reconciliation(Interview with John Bosco Ekanem, 2019).

In an interview with Chief Sunday Akpan at Ediene, (2019), with the emergence of the court system, if after resolving an issue, an unsatisfied party can sue it to the court, most often the High Court (Esop afong isin). The court honours the judgment made at the traditional institution, and it is sustained if looked at to be impartial and just. In many civil cases, Esop afong isinhas been noted for sharing of property.

\subsection{Truth Determinants in Annang Traditional Society}

In cases of protracted disagreements, denials and obstinacy, the traditional institutions resorted to certain truth determinants which included Oath (Mmiam), Divinantion (Iyong) and Ordeal (Ukang).

\subsubsection{Mmiam}

Mmiam was often prepared, though with variations. In whichever way it was prepared, the combination of items and actions used for the ritual was very symbolic. In an interview with John Bosco Ekanem at Abak, (2019), one of such instances was the digging of a pot-like hold (ube) in the earth, and palm wine (ukot Nnwon) was poured into it together with local gin (kai kai). Thereafter, a goat was slaughtered and the blood mixed together in the hold. It was scooped and given to the oath taker to drink, while he swears. He did this with ajei (young palm front) placed on his head. All these portrayedmmiam as the god of justice. Of course, the earth deity (ikpaisong) was the god of justice and litigation, the drink was something spiritual, the blood symbolized life and the young palm fond was a symbol of authority of the elders. There was a conjuration of the sky, the earth and the world, bearing witness to the truth about to be spoken.

In oath taking there was no appeal available. There was a duration set for the oath to take effect after swearing, during which the person is expected to suffer some affliction, which is often death. If this does not happen within the set period, then he is to be publicly declared innocent (Essien, 2011). As part of the oath-taking, he must mention that he has not or will not do anything to prevent the effect of the oath. On the other hand, prayed against unjust victimization. The plaintiff also had to swear that he would not do anything to harm the oath-taker on the pretext that it was the oath that really harmed the 'guilty' (Umoh, 2009).

\subsubsection{Iyong}

Awia Iyong possessed expert powers to invoke the spirits or the gods. It was believed that the gods and ancestors communicated the truth through him. Iyong was similar to other truth determinants like nkukud (oracle) and usemkpo(foretelling) (Essien, 2011).

\subsubsection{Ukang}

Ukang was instituted to detect and punish offenders. It was magical, mysterious and supernatural with physical and material effects (Essien 2011). 


\subsection{The Role of Ajei in Conflict Resolution Annang Traditional}

In certain civil matters like land litigation or landed property dispute, some prohibitions called injunctions were made as a signof "no trespass", by hoisting Ajei (young palm frond) on it. Most often Ajei was hoisted by Nkuku constituting the Afe Annang, the highest political unit in Annangland. Whoever disobeyed the Ajei injunction was either made to pay a certain fine or visited with some supernatural punishments.

Ajei also serves as a mediatory symbol of peace sent by the traditional institution or other third party to the parties at conflict calling for a moratorium and summoning them for a peaceful resolution of their differences, and for reconciliation.

\section{Findings}

We found out that unlike most African traditional conflict mechanisms, conflict resolution in Annang traditional society was not entirely restitutive but also retributive. In some cases, like murder, the offenders were made to pay with their lives. Theft and Adultery were also handled in very crude ways, and even with capital punishment too. Even those who swore falsely or went against taboos were identified by swollen bodies and even death. Attendant in these and similar cases was the evil of abandoning the victim and community and emphasizing the crime and punishment of the offender, without any aim of sustainable reconciliation and healing of relationships. It is in line with this that Essien (2011) observes that there is a lot to be modified in Annang native laws and customs especially those laws that are inconsistent with natural justice, good conscience and equity.

\section{Conclusion}

Besides, the mechanisms described above, the family, clan and village courts made great use of arbitration. This involved an agreement by the parties, first to reconcile, on choice of panel/ venue, then to comply with the panel (Essien, 2011). The Annang traditional society had a well-established and institutionalized judicial system. This has stood the test of time despite the influence of colonialism and western education, owing to its efficacy in conflict resolution. Despite modernism, the Annang people are very slow to embrace the formal court process to resolve conflict, because of the advantages evident in the traditional system. It is more reliable and satisfactory, less expensive and less time consuming, more accessible and very participatory.

\section{Recommendations}

We recommend that the Annang traditional conflict mechanisms should be made to exist side by side with the modern judicial system as it will help in a rapid reduction of conflicts and more satisfactory and fulfilling conflict resolution in the society. Second, the arbitrators in Annang nation should uphold the integrity of the judicial system by living up to their moral expectations, never to manipulate the process of conflict resolution for their selfish purposes. Lastly, the Annang indigenes should always seek redress at home for every misunderstanding, for there truly lays the solution.

\section{References}

i. Ayitte, G. (1991) Indigenous African Institution: Irvington-on-Hudson. NY: Transnational publishers Inc.

ii. Barash, D. P. and Webel, C. P. (2002) Peace and Conflict Studies. CA: Sage Publications.

iii. Essien, E. S. (2011) Annang Philosophy, History and Culture. USA: Lulu Press.

iv. Etim, F. (2005) Metaphysics of African Medicine. Uyo: Minder International Publishers.

v. Gbenemene, K. (2018) Traditional Mechanism for Conflict Management and Resolution in Ogoni, South - South, Nigeria, International Journal of Social Sciences and Management Research, Vol. 4(4) pp 37-44

vi. Jeong, H. (2000) Peace and Conflict Studies: An Introduction. Aldershot: Ashgate.

vii. Maduka, E. (2009) "African Metaphysics" in From Footmarks to Landmarks on African Philosophy A. F. Uduigwomen (Ed). Lagos: O. O. P Limited

viii. Nicholson, M. (1992) Rationality and the Analysis of International Conflict. London: Cambridge university Press.

ix. Udondata and Ekanem (2011) in Essien(2011) Annang Philosophy, History and Culture. USA: Lulu Press

x. Umoh, Dominic (2009) The Annang personality. Enugu: Snaap Press.

xi. Interview with John Bosco Ekandem at Abak, 2019.

xii. Interview with Sunday Akpan at Ediene, 2019. 